\title{
The Students' Perspective Contribution: Rethink the Ethical Education of Engineering Students
}

\author{
https://doi.org/10.3991/ijep.v7i2.6819 \\ Fátima Monteiro \\ Instituto Superior de Engenharia de Coimbra - IPC, Coimbra, Portugal \\ fatcmontaisec.pt
}

\begin{abstract}
The inclusion of ethics education in engineering courses has been recognized as fundamental. However, in Portugal this training component is present only in a small number of courses. Teachers are mainly responsible for building the curriculum, but students are the ones most affected by this absence of ethics education. In this context it is necessary and important to understand students' perspective, because their role is vital in the curriculum construction's success. It is in this framework that this investigation listened to engineering students' voice as a factor to consider in the rethinking of engineering course curriculum in the ethics education area. This study highlights the concept that students have of engineering action, their perspective about the possibility of their courses to include ethics training and its practical implementation. This research is part of a case study and research-action. The results indicate that students are very receptive to this training component, and they consider that it should be included as mandatory in engineering courses. The results also show that students prefer a more practical training with 'prescription' characteristics and that their perspective of engineering action consequences is very limited. These results reinforce the need for ethics education that promotes a wide scope critical reflection.
\end{abstract}

Keywords—ethics education, engineering education, engineering conception, students' voice

\section{$1 \quad$ Introduction}

In the contemporary context, according to [1], engineering is probably the professional activity with the greatest impact on society. In fact, the presence of engineers' action is so incorporated into the day-to-day, that society has become dependent on engineering, without really being aware of its action. Even though, engineering fosters action, progress and well-being, but it also involves a dangerous and even life threatening side.

It becomes evident that the technical knowledge that engineers receive as part of their course is "powerful" [2], but raises the question of how this knowledge is being used [3]. It is not enough to provide the tools, it is also necessary to teach them how to use them for the common good [3]. For such, several authors and organizations 
consider essential promoting ethical education and reflection, developing a more accurate view of how engineering can responsibly fulfill their commitment to society $[1]$.

\subsection{Presence of ethics education in the Portuguese engineering course curriculum}

The foregoing is a clear indicator of the need to include ethics education in engineering courses. However, parting from the study in [4], in Portugal the presence of ethics and civic education in the engineering course curriculum is still low $(22 \%$ of the courses have compulsory curricular units incorporating ethics education, but only in $7.6 \%$ of the courses it is incorporate as a compulsory curricular unit completely dedicated to the ethics education component). This data seems to indicate that higher education institutions, which teach engineering courses, do not give enough importance to ethics education to integrate this training into their course curriculum.

To understand the low presence of ethics education in engineering courses, despite the many (international and national) recommendations, it is therefore important to analyze 'why' the curriculum settings incorporate or not this training component. Such decisions are rooted in different perspectives and concepts that underlie the diversity in curriculum options.

It is necessary to take into account that historically engineering was considered neutral from an ethical point of view, therefore engineers didn't need an ethical and moral education [3]. This assumption was grounded in engineering conception as a technical action tool, as such without relevant social intervention.

However, this engineering conception didn't take into account the influence of engineering in society, neither regard their role in the humanity welfare development, and its negative effects (namely environmental). Thus, time has shown that engineering is not neutral, and that the engineer is a strong actor with social, political and environmental intervention. Nonetheless, this evidence is not yet reflected in the ethical education in most engineering course curriculums in Portugal [4].

On the other hand, some teachers argue that it is not necessary to include ethics training in engineering courses because students are adults, with their moral and ethical education already consolidated, and therefore little receptive to significant behavioural changes [7].

It is also important to note that the absence of explicit ethical education in engineering courses affects mainly their students, by denying them a full education, but also has having a negative impact on society. In this sense, [12] argues that higher education institutions form "docile" engineers who are unable to interpret the social and contemporary political reality, and are unaware of the consequences that specialized knowledge action' has on social and human actuality [13].

In this line, it can be argued that, although ethics and civic development are fundamental to society and democracy, it is also important for young people, because they can be more successful if they are involved and committed to their community and the common good [14]. In this perspective, ethics and civic education do not aim 
merely at social development, but also at youth development, so this is also in the students' personal interest.

\subsection{Should ethics education be integrated into the engineering curriculum?}

Reference [3] and [15] argues the need for higher education to promote the ethical education of their students. According to [3], it was found that primary school education and high schools have little influence on students' political beliefs and values. This reinforces the role that higher education can and must have in order to promote the ethical development of their students. Thus, the author argues that higher education should not be limited to a database, but should promote and develop skills so that their graduates can act in the world with reflection and wisdom. With this goal in mind, the author believes that higher education should promote the moral, civic and political development, which implies the ability to develop a more sophisticated and conceptually more advanced understanding of the social complexity and of the ethical concepts, which will result in greater intellectual growth.

It is also important to note that, according to [16], moral development is part of identity and personality development. For this author, in contemporary society, the content selection process that defines the identity and is associated with ethics, moral development and motivation, only occurs in emerging adulthood that is between 18 and 25 years old. As per this data, mostly higher education students are still in this ethical and moral development phase which is of vital importance and a reference to their values and respective identity integration.

This author also states that "the level of integration of moral knowledge in identity seems to vary according to motivation" [16]. Thus, taking into account the age range of the majority of higher education students, the (theoretical and practical) ethics and moral education is relevant, in order to provide greater moral identity and integrity, the main predictors of moral motivation in future actions.

Various methods are used in higher education to promote ethics, civic and students' deontological education [3] [17] [18]. Within the engineering courses, according to [18], there are 3 main methods: Specific Curricular Units (CU); Modules that have a large amount of technical areas in the (CU), and that deal with specific cases (for example, lectures); Short training inserts in the various $\mathrm{CU}$ that are part of the curriculum.

However, it is necessary to consider that ethics education can be promoted as an ethical training focused on deontological ethics (based on the duties set for professional codes), and as such more individual and normative; or in a broader aspect of ethics, that is not limited to professional codes or individual action, but includes the social, political construction, incorporating the collective dimension, social and environmental in the present and in the future. The conception of engineering and of the consequences of its actions, are one of the most crucial aspects in the choice of ethics education profile for engineering students. A conception in which the role of the engineer is confined only to the technical sphere, will lead to a delimited deontological training; and a broadened conception in which engineering is recognized as having an active role in the social-political level, will lead to a wider and deeper ethics training. 


\subsection{Should ethics education be included in the engineering course curriculum? What do students think about this?}

The following highlights the importance of the teachers' role in curriculum development and as such in the inclusion, or omission, of ethics education in engineering courses. While teachers are the main curriculum builders, students are also involved in this process [6]. On the other hand, students are the ones mainly affected by the absence of an ethics educational project within their courses. These two aspects show the need to take into account the point of view of engineering course' students about the inclusion of ethics education in their course.

According to [20], it is necessary to take into account the students' perspective to improve their course curriculum and results, it is therefore essential to speak with them, listen to their voice, because their voice has a strong transforming potential [21]. However, it is also necessary to take into account that students are often unaware of the various curricular possibilities, as well as the values and concepts underlying them [21].

It is therefore important to investigate the students' perspective on this issue: they consider ethics education has necessary or useful in the engineering courses? It should also be investigated if they are receptive to this training area or if they consider that this is inadequate, because they are already adults with moral and ethical principles? Lastly, how do they think this training field should be implemented and put into practice?

It is also important to know the concept that students have of engineering, as this will influence their perspective about ethics training. Knowing the conception of engineering and the consequences of its action allows conceiving an ethics training that is more adjusted to the students' needs.

So, the present study fits within this context and aims to listen to the students' voice in order to investigate:

- Students' conception of engineering's action in society;

- Students' perspective on the inclusion of ethics education;

- Students' perspective on the practical implementation of ethics training;

- Students' perspective on the topics to be included in ethics education.

\section{Methodological options}

These objectives fall into a quantitative and interpretative perspective [19]. The framework in the phenomenological interpretative perspective is associated with the guidance that underpins the research and the object of analysis and not only with the specificity of the methods.

Thus, in the present research, a volunteer student group belonging to engineering courses that do not include ethics education in their curriculum was interviewed.

The study included ethics training and a debate, allowing students a better mastery of the topic in question, so that students aren't restricted in their expression due to the limited conceptual domain of the subject under study. It is therefore a case study [22] 
which is both research and ethics education, and as such with a potential for social transformation, i.e. a research-action [23].

Given the characteristics of the study, the intention is not to make a statistical generalization of the results obtained, but instead, to hear the students' personal voice that leads them to reflect and comment on curriculum construction. This action can already be considered a form of ethics and civic education.

\subsection{Study Implementation}

Twenty five polytechnic higher education engineering course volunteer students were part of this study. The choice of the institution selected for this study was based on the researcher's convenience. The courses' choice for the study was done selecting a curriculum that did not include any $\mathrm{CU}$ or other explicit form of ethics education, so as not to influence the students to the use of any specific form of ethics education.

The study took place in two phases: initially, before the training, the volunteer students answered a pre-training survey composed of open and semi-open questions; and in the second phase (after 8 hours of ethics training divided in two days), students answered a post-training survey with open questions, semi-open and closed (Likert scale) questions.

A content analysis procedure was used in this study to analyse the data collected (for open answers) to find out what the students' views and perspectives were. The use of content analysis is based on its ability to interpret perspectives, as well as their versatility [24]. A descriptive statistical analysis of the answers was also done.

The group was composed of 25 students, from 3 engineering areas (electrical engineering, biomedical engineering and electro-mechanical engineering) from licentiate and Masters Degree.

\section{Results and their Analysis}

\subsection{The students' conception of engineering's action in society}

Before the training, students responded to a survey aimed at finding out their perspective on: the engineering action in contemporary society; positive and negative contributions; and about the most important values in the performance of the engineering profession.

Relative to the most important values for the practice of the engineering profession, Figure 1 shows the results in the categories identified in the responses.

From the analysis in Figure 1 it can be concluded that the students had mixed responses, values, skills and/or competences, by mentioning, for example, the "ability to work as a team", of "being proactive" or "meet objectives" as important values for the engineering. Thus, $29 \%$ of the students reported that the most important aspect is to be able to work as a team, and $22 \%$ reported honesty, responsibility and humility as indispensable values to this professional activity. Followed by professionalism and respect, in $18.5 \%$ of the responses. Also highlighted is the fact that students consider 


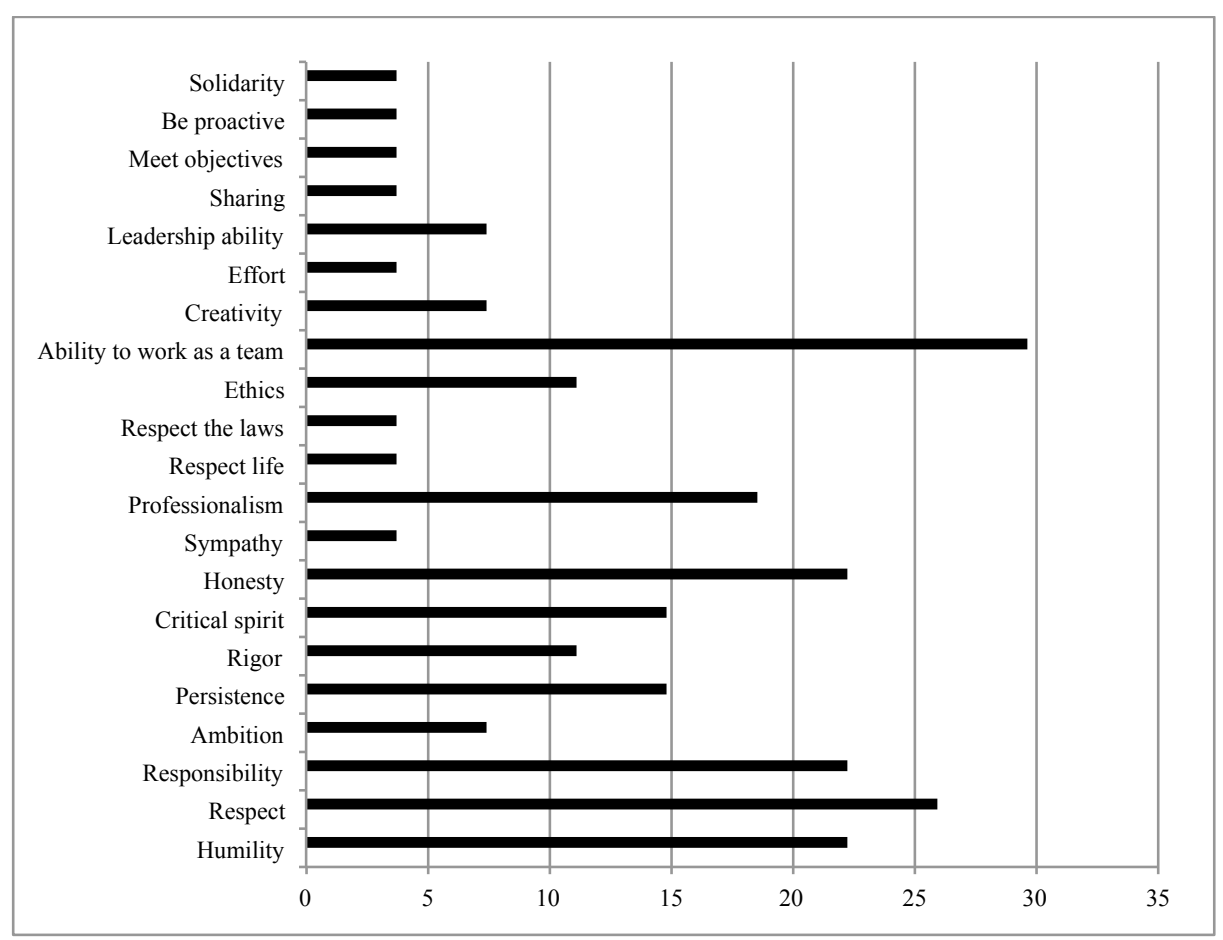

Fig. 1. The most important values in the exercise of the engineering profession as per students' opinions ( $\%$ of total students).

the capacity or competence to work as a team, as being most important in the face of so many values such as honesty or justice. It can also be stressed that $7.5 \%$ of the answers considered that the most important value for an engineer is, ambition, and that $3.7 \%$ consider it important that the engineer be "meet objectives". Most of the answers submitted are indicators of the engineer's perspective as a technical instrument [26], and as such to be technically competent, and not as an actor who intervenes in the social construction, and as such without the need of ethical and moral values.

To better clarify what perspective students have of engineering, they were asked to choose the phrase that best defined the importance of engineering in society. These results show that the majority of students $(52 \%)$ identifies themselves with the ideology of progress [26], which gives engineering the role of being the engine behind development and progress. The second most selected option (22\%) corresponds to the belief in the technical and scientific development ideology [26], in which this is seen as a good in itself. The option least selected $(11 \%)$ corresponds to the ideology of economic development, in which engineering is seen as fundamental to the entire production process [26]. The option corresponding to the ideology of creativity was chosen by $15 \%$ of the students. Most answers highlight not only the belief in the progress ideology, but expressed as well the belief that the potential of engineering is limitless. 
Students were also asked about the image that society has of engineers. $80 \%$ of students considered that the image is very positive and only $20 \%$ consider it a negative image. Some of the answers demonstrate the extremely positive belief that the students themselves have of Engineering: "they are well regarded by society as it is a profession that creates many jobs and brings to the citizens new technologies and wellness"; "I see them as people in our society that help promote the development of the country and solve the practical problems of our society"; "these are people with a lot of knowledge in their area, with huge capabilities to contribute to the progress and development of technologies or even to humanity". These responses also show their belief in the ideology of progress.

$14.8 \%$ of the students did not reply to the open question about the best impact/influence of engineering in society. From the responses obtained a set of 10 categories was identified, the results are shown in Figure 2.

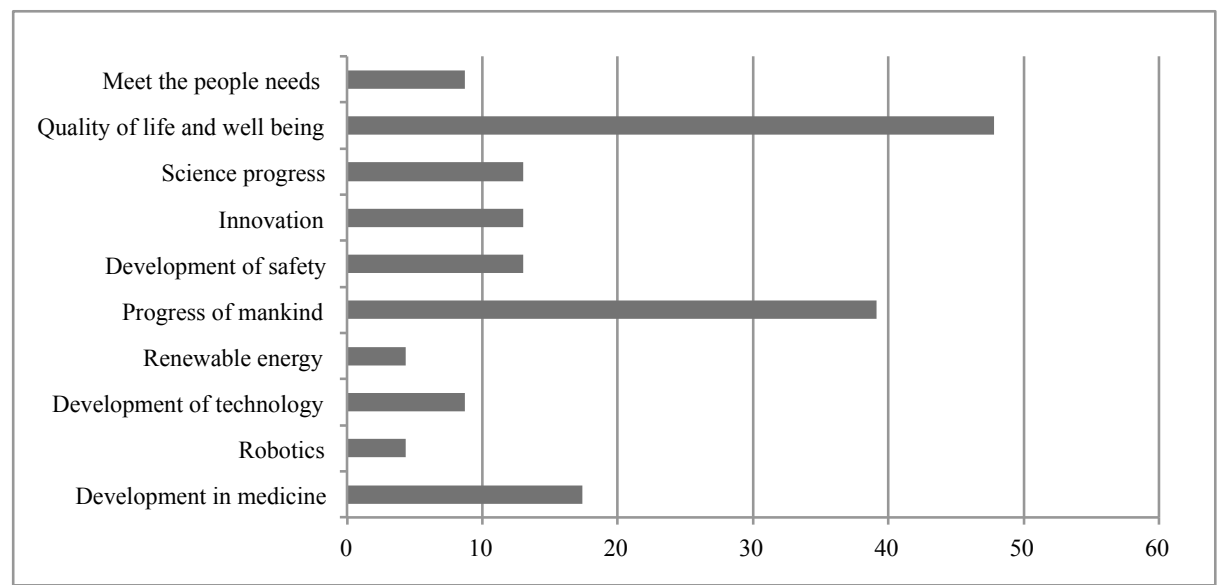

Fig. 2. Answer to the open question about the best impact/influence of engineering in society (\% of total students).

The category most referred to where engineering is making the strongest contribution to society was quality of life improvement and well-being $(47.8 \%)$. Some answers highlight the high expectations of students: "engineering has a great impact on society, as it allows increasing the standard of living and welfare of the people, regardless of the area or the planet where they are living"; "I think engineering has an impact throughout society, which would not even exist without the contribution of engineering"; "the greatest contribution of engineering is to turn fiction into reality". These replies strengthen the perspective of the belief in the progress ideology and the unlimited nature of engineering potential.

The students were also asked about what the worst impact/influence of engineering on society was. From their answers 13 categories were identified which are shown in Figure 3. 


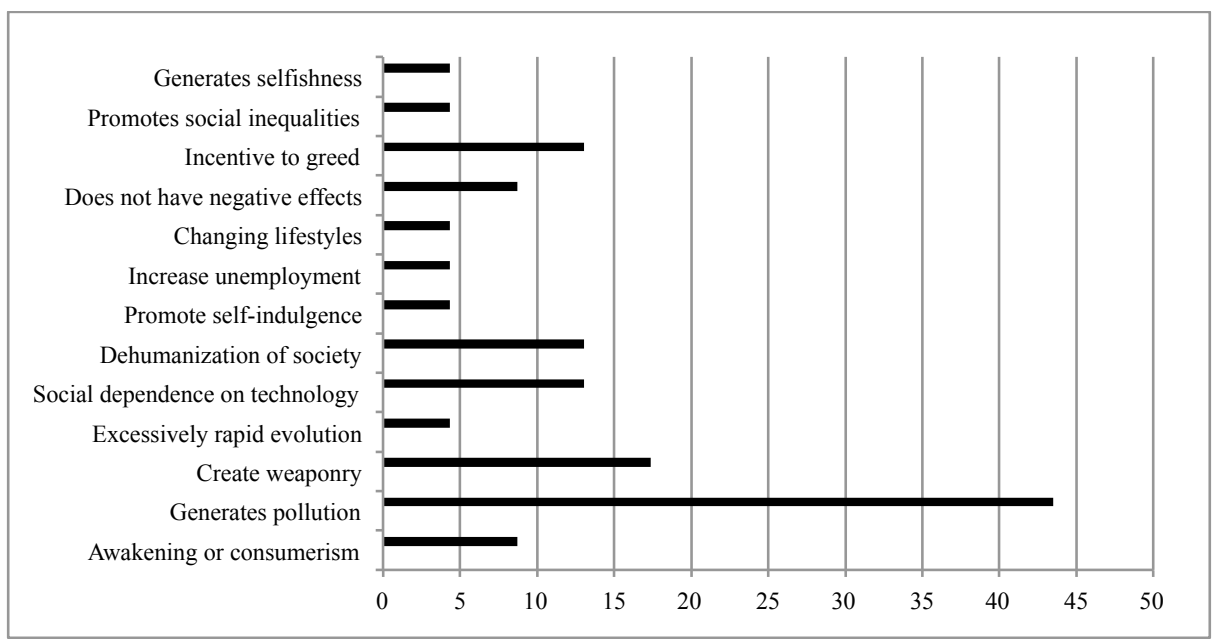

Fig. 3. In the students' opinion, what is the worst impact/influence that engineering has on society ( $\%$ of total students).

The response of $43.5 \%$ of the students referred to the worst impact, as being pollution, followed by armament $(17.4 \%)$ and $13 \%$ of the choices were social dependence on technology, the dehumanization of society and an incentive to greed. It should also be noted that $8.7 \%$ of students reported that Engineering has no impact or negative influence on society.

One of the answers absolves engineering of any wrongdoing: "the worst impact is not created by engineering, but by the people who channel their knowledge to harm humanity". Another answer shows a more complex association between different levels of impacts that interrelate: "I think engineering leads to evolution, which awakens the consumerism and ultimately creates inequality, because the developments are always more accessible to social groups with higher purchasing power; and more and more people tend to think of evolution as a way to get rich and not to help others ".

In synthesis, they were asked if they thought engineering contributes to a "better world" and if so how. The answers highlight the belief in the supremacy of Engineering: "without a doubt. Where would we be today without engineering? Engineering came to bring a great development and make daily life a lot better for all inhabitants of the planet"; "yes, without a doubt, its contribution brings people happiness, making them dream"; "yes, it increases time and quality of life, facilitates rapid knowledge sharing and information and all this makes the world a better place"; "yes, with engineering its possible for humanity to evolve". However, some responses recognize some doubts: "engineering can create a near-perfect world, but people have a duty to continue to be human and not let everything turn into machines"; "I think so. At a time when there are actual facts that the world is getting worse at our expense, engineering is being redirected to what is correct for the world, rather than to what is comfortable for us. "

One reply highlights the belief in the neutrality of Engineering: Engineering "does not contribute to a better or worse world. Contributes above all to people's needs ". 


\subsection{Students' perspective on the inclusion of ethics education}

Before and after training students were asked what they thought about the possibility of including ethics education in engineering courses. Results show that before training, the majority $(89 \%)$ of the students thought this training component should be included in the curriculum, and some of them state that it should not only be in their course, but in all higher education courses. However, $11 \%$ of students stated that they did not know because they consider themselves unaware of the matter.

After training, the results show that $100 \%$ of students consider that ethics education should be part of their course. On one hand, the training clarified that some students had doubts about it, on the other hand it increased the degree of belief that many students, manifested through expressions and answers that went far beyond a simple "Yes" (which was the most frequent response prior to training). This strengthening conviction was expressed by statements such as: "Undoubtedly yes", "yes, no doubt"," yes, it's a must!","Yes, I think it is a fundamental curricular unit", "Yes, without a doubt".

\subsection{Students' perspective on the practical implementation of ethics training}

As mentioned in the introduction of this study, the recognition of ethics education being needed in higher education courses seems to be quite consensual, but there is no consensus concerning the practice of such training [7]. Thus, the students (who are the ones who have the most to lose or gain in this process) were asked about the practical way this training should be implemented. This question was asked before and after training.

From the results it appears that prior to training $48 \%$ of the students thought that this educational component should be incorporated into the curriculum as a compulsory CU. The remaining students' answers were broken down as follows: $7.4 \%$ believe it should be an optional CU; $14.8 \%$ think it should be extracurricular training; $22.2 \%$ thought it should be as some form of short training; and $18.5 \%$ believe it should training distributed throughout the various technical CU (note that the sum of these values exceeds $100 \%$ because some students had more than just one answer).

After the training, all options decreased significantly, except the conception of ethics education based on a compulsory $\mathrm{CU}$, which increased to $52 \%$.

\subsection{Students' perspective on the topics to be included in ethics education}

During the training six topics were addressed: Ethics and moral concepts; Framework and ethics, historical evolution; Contemporary ethics; Engineering action consequences on society and the environment; "Ethics for engineers" [1]; Professional Code of Ethics (from engineering professional entities).

After the training, the students were questioned about the training usefulness for their personal life and their future professional life. The results show that none of the students feel that the training was useless or of little use. As per whether or not it was useful for their personal life, $24 \%$ considered it fairly useful and $76 \%$ very useful. 
Pertaining to how useful it was for their future professional life, $8 \%$ considered it fairly useful and $92 \%$ very useful.

In order to investigate whether the training in question had brought something new to students, they were also asked if the training allowed them to discover, learn or understand any subject they deemed relevant. $60 \%$ of the students answered that the training allowed them to discover, learn or understand some issues they considered relevant, and $40 \%$ that the training allowed them to discover, learn or understand many relevant issues.

As to better understand what topics students considered most relevant to ethics education in engineering courses, students were asked which topics they would exclude from the ethics education, and what topics should be included. The answers are presented in Figure 4.

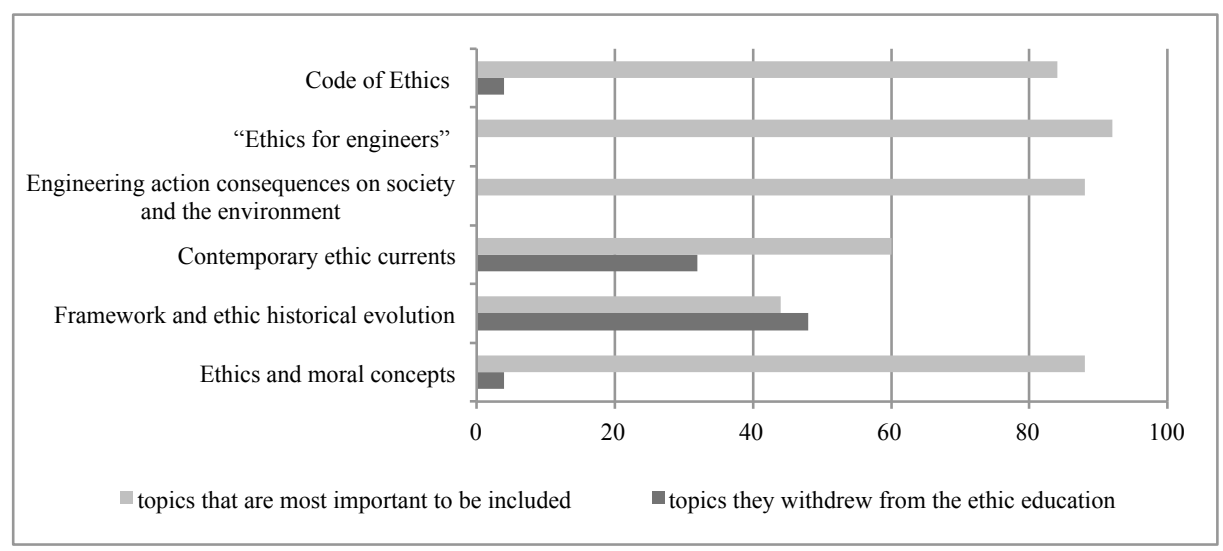

Fig. 4. students answers (\% of total students): "From the topics covered in the training, which would you remove and which ones would do you consider most important?" [27].

The results show that students consider all topics are important, and only in one case - Historical ethics framework - the number of those who removed this from the training was greater than those who considered it important. However, the difference between those who would exclude it and those who consider it important is only $4 \%$, which corresponded to one student's answer.

It should also be noted that the least valued topics are the most theoretical, and the most valued are those that demonstrate the practical application of ethics to real engineering case scenarios. This fact is consistent with the profile of engineering students that, in general, value more the practical component of their course. In this sense, students often expect (and are used to) follow rules and procedures that act as "prescriptions" for action, not to reflect and critically and theoretically analyze multifaceted and complex issues.

Thus, it is necessary to take into account that, in general, engineering courses do not encourage reflective practice, and that, on the contrary, often favor knowledge' memorization and mechanization [25], in the application perspective and not of reflection. This increases the difficulty of students in broadening their vision beyond the 
purely technical application (works or does not work) to see their actions in the broader context of society and environment (ethical, political, environmental and social relations and consequences).

Students were also asked about the negative aspects of the training and improvements to be implemented in future editions. The main suggestions were that the number of examples and discussion of "real life" case studies ("Increase analysis / case discussion of real life (what you would do if....)") should be increased. This aspect is consistent with the perspective of a "prescription" training type already mentioned and the indication that it should have less theoretical issues.

Another aspect mentioned was the fact that the training was very short ( $8 \mathrm{~h}$ ) and being that it was so limited there was no time for all participants to share their views ("I think it should be mandatory). If it is not possible, at least it should be longer so as to give students more time, to share their opinions, which will create an opportunity for these issues to be further discussed. ").

\section{Conclusions}

The results show that the conception of engineering action that students defend is based mostly on the ideology of progress, and that the action of engineering is regarded as essentially positive and unquestionable. They also consider that the engineering potential is unlimited and features a limited awareness of the possible consequences in the various social-environmental areas. In this context, their answers were limited to the most obvious consequences: quality of life improvement/well-being as a positive effect, and pollution/armament as negative. However, only a very reduced number of students referred to the fact that the benefits (in terms of quality of life and well-being) are not accessible to all people, or the nefarious connection between the economic exploitation of the technology created by engineering and the social and moral behavior change.

These aspects reinforce the need for students to have ethics education, in order to broaden their awareness of the limitations and potential social-environmental consequences of the various ideologies that are associated with engineering, promoting the recognition of its role within the complex contemporary sociopolitical construction. Thus, these results reinforce the need for engineering students' ethics education to promote critical reflection on the action of engineering and on the concessions that are associated with it, for example, through the study and reflection of engineering history.

The results also show that the engineering students who participated in this study consider it necessary to incorporate ethics education in engineering courses, as a compulsory Curricular Unit.

It also shows that some students had doubts about this issue, since they do not consider themselves well-informed about the subject in question. In this sense, the training implemented during the study provided the students' with clarification and exemplifies some important themes that can be incorporated into the ethics education of engineering students. The results show that this training was a clarification that result- 
ed in students' greater conviction about the importance of incorporating ethics education in the engineering curriculum, and increased the demand for a mandatory ethics education in Curricular Unit format.

Thus, these results question the argument that higher education students, as adults, are unreceptive to this training area [7]. This aspect is also highlighted by the voluntary and significant students' participation in the proposed ethics training referred in this study.

The results also show that students believe that the ethics education domain is useful for both: their personal life and professional future. The students considered the ethics education they attended as a learning opportunity for relevant issues, which reinforces the conclusion that they are receptive to ethics education, and that it can bring learning opportunities, reflection and "broaden horizons", and as such, have the potential to be a strong personal and professional ethics development tool.

The results also indicate that the students in question value a more focused training in practical cases and its discussion, and place less importance on the theoretical foundation component and understanding of the ethical currents. This indicates a "prescription approach" and less of a theoretical / reflective perspective. This view may be rooted in the engineer conception of being just a technical tool, and not as strong sociopolitical co-builder. In this sense, the central concern is more focused on a concrete, practical issues response, than a "sense of the world" reflection that theoretically justifies a particular direction for social construction evolution. This result is in accordance with the concept and perspective that engineering students have expressed, which does not evidence a potential action at the sociopolitical level, but only technical and at the economy and well-being level. These results reinforce the need of rethinking engineering education that incorporates the ethical education of its students and that promotes a wide critical reflection enabling them to become aware of the role that engineering plays in different domains: social, political, economic, environmental, moral, etc.

Given the small group size and the fact that $76 \%$ of the study participants were male and predominantly from the electrical engineering area, it will be necessary to continue the study with participants from both genders and different engineering areas.

\section{$5 \quad$ References}

[1] Rego, A. and Braga, J. (2014). Ética Para Engenheiros. $3^{\mathrm{a} e d, ~ L i s b o a: ~ L i d e l-~ e d i c ̧ o ̃ e s ~ t e ́ c n i-~}$ cas.

[2] Young, M. (2010). Conhecimento e Currículo: do socioconstrutivismo ao realismo social na sociologia da educação. Porto Editora.

[3] Ehrlich, T. (2000). Civic Responsability and Higher Education. Americam Council on Education e Oryx Press.

[4] Monteiro, F., Leite, C. and Rocha, C. (2016). Ethics and Civic Education in the Curriculum of Engineering courses in Portuguese Higher Education System. 8th International Symposium on Project Approaches in Engineering Education (PAEE) and 14th Active Learning in Engineering Education Workshop (ALE) Proccedings. 
[5] Durham, E. (1989). A Autonomia Universitária: o princípio constitucional e suas implicações. Núcleo de Pesquisas sobre Ensino Superior - Universidade de São Paulo.

[6] Leite, C. (2011). Questões do currículo no ensino universitário: O que distingue a organização e o desenvolvimento do currículo deste nível de ensino?. In Leite, C., Pacheco, J., Moreira, A. and Mouraz, A. Políticas, Fundamentos e Práticas do Currículo. Porto Editora. pp 278-287.

[7] Oliveira, L. and Afonso, J. (2016). A ética como objeto de ensino. In Almeida, F., Seixas, A., Gama, P., Peixoto, P. and Esteves, D. (coord). Fraude e Plágio na Universidade. Coimbra University Press. pp 145-152. https://doi.org/10.14195/978-989-26-1123-5 6

[8] Leite, C. (2003). Para uma Escola Curricularmente Inteligente. Edições ASA.

[9] Shay, S. (2014). Curriculum in higher education: Beyond false choices. In Gibbs, P. and Barnett, R. (Eds.).Thinking about Higher Education. Springer International Publishing. pp139-156. https://doi.org/10.1007/978-3-319-03254-2 10

[10] Driel, J., Verloop, N., Werven, H. and Dekkers, H. (1997). Teachers' craft knowledge and curriculum innovation in higher engineering education. Higher Education Journal, 34 (1). pp105-122. https://doi.org/10.1023/A:1003063317210

[11] Rovira, J. (2003). Prácticas Morales - Una Aproximación Moral. Ediciones Paidós Ibérica.

[12] Nussbaum, M. (2014). Educação e Justiça Social. Edições Pedago.

[13] Giddens, A. (1998). As Consequências da Modernidade. Celta Editora.

[14] Levine, P. (2015). The Future of Democracy: Developing the Next Generation of American Citizens. Tufts University Press.

[15] Estrela, T. (2010). Ética e pedagogia no ensino superior. In Leite, C. (org.). Sentidos da Pedagogia no Ensino Superior. CIIE/Livpsic. pp11-27.

[16] Ferreira, J. (2013). O Que Nos Leva a Ser Morais? A Psicologia da Motivação Moral. Climepsi Editores.

[17] Jacoby, B. (2009). Civic engagement in today's higher education: an overview. In Jacoby, B. (org). Civic Engagement in Higher Education: Concepts and Practices. Jossey-Bass Books. pp 5-30.

[18] Davis, M. and Feinerman, A. (2012). Assessing graduate student progress in engineering ethics. Science \& Engineering Ethics, 18(2). pp 351-367. https://doi.org/10.1007/s11948010-9250-2

[19] Lessaed-Hérbert, M., Goyette, G. and Boutin, G. (1994). Investigação Qualititiva: Fundamentos e Práticas, Lisboa: Instituto Piaget.

[20] Rubin, B. and Silva, E. (eds) (2003). Critical Voices in School Reform: Students Living through Change, Routledge.

[21] Rudduck, J. and Flutter, J. (2003). How to improve Your School: Giving Pupils a Voice. Continuum International Publishing.

[22] Yin, R. (2001). Estudo de Caso: Planejamento e Métodos, $2^{a}$ ed, São Paulo: Artemed Editora.

[23] Nunes, R. (2006). Investigação-ação e Inovação em Educação, Edição do autor - Relatório apresentado ao concurso de Professor Associado da FPCEUP.

[24] Guerra, I. (2010). Pesquisa Qualitativa e Análise de Conteúdo: Sentidos e Formas de Uso. Editora Princípia.

[25] Marchand, H. (2008). Desenvolvimento intelectual e ético em estudantes do ensino superior - implicações pedagógicas. SÍFIFO - Revista de Ciências da Educação, n.7. pp 9-17.

[26] Dubreuil, B. (2007). Imaginaire Technique et Éthique Sociale. Instituto Piaget.

[27] Monteiro, F. (2016). Include ethics education in the engineering curriculum - the students' perspective. Proceedings of CISPEE2016- 2nd International Conference of the Portuguese Society for Engineering Education. https://doi.org/10.1109/CISPEE.2016.7777726 


\section{Author}

Fátima Monteiro (fatcmont@isec.pt), since 1995 is professor in the Instituto Superior de Engenharia de Coimbra (www.isec.pt) (Coimbra Engineering School, Portugal). Have an academic background in Electrical and Computers Engineering, in Education and Adult Training and Education Science (Universidade do Porto). The current interests of research are within the interconnection between engineering education, philosophy and educational sciences, mainly in the field of ethics and civic education of engineering students'; in the conception of the engineer as an social and political actor; in the assessment of learning and in the designed and implementation of curriculum in engineering courses.

This article is a revised version of a paper presented at the 2nd International Conference of the Portuguese Society for Engineering Education (CISPEE2016), held 21 and 22 Oct, 2016 , at UTAD, Vila Real, Portugal. Article submitted 28 February 2017. Published as resubmitted by the author 04 April 2017. 